\title{
Evaluation of Quality Parameters of Food Barley (Hordeum Vulgare L.) Varieties as Affected by Blended NPSB Fertilizer Rates in Central Highlands of Ethiopia
}

\author{
Abdisa Mekonnen Habtamu Ashagre Girma Chala \\ Ethiopian Institute of Agricultural Research (EIAR), Holeta Agricultural Research Center (HARC), \\ P.O. Box. 2003 Addis Ababa, Ethiopia
}

\begin{abstract}
Barley (Hordeum vulgare L.) is the most health benefits among cereal crops which were grown mostly in central highlands of Ethiopia. The three food barley varieties (EH1493, HB1966 and HB-1307) which were released by Holeta Agricultural Research Center (HARC) had experience on barley breeding program (his center of excellence) was evaluated for their grain flour quality content and proximate analysis with respective to five blended NPSB fertilizer rates $\left(0,100,150,200 \& 250 \mathrm{~kg} \mathrm{NPSB} \mathrm{ha}^{-1}\right)$ and one Recommended NP $\left(60 \mathrm{~kg} \mathrm{~N}\right.$ and $\left.69 \mathrm{~kg} \mathrm{P}_{2} \mathrm{O}_{5} \mathrm{ha}^{-1}\right)$ fertilizer rates. To evaluate their proximate analysis and grain flour quality contents of the food barley varieties were determined by using suitable Standard Official procedures. Proximate analysis was determined according to Association of Official Agricultural Chemists (AOAC) method and TKW, MC, HLW, GS, GE, PC, FC, AC, CHO, $\mathrm{SC}, \mathrm{FC}$, and BG contents of food barley flour was analyzed. All quality and proximate analysis result means were statistically significant and in the range of acceptable recommendation according to FAO and other nutritional sources. The quality parameters analysis showed that EH1493 variety has an average moisture content $(11.78 \%)$, Hectoliter weight $(66.26 \%)$, and friability $(68.43 \%)$, while grain size $(80.46 \%)$ and Bet-glucan $\left(861.81 \mathrm{mgL}^{-1}\right)$ were higher with HB1966 variety. Moreover, 200kg NPSB ha $\mathrm{kg}^{-1}$ gave the maximum protein $(10.31 \%)$, fat $(2.51 \%)$, and ash $(2.64 \%)$, while the highest total carbohydrate $(82.88 \%)$ content obtained on $250 \mathrm{~kg}^{\mathrm{NPSB}} \mathrm{ha}^{-1}$. The economic analysis revealed that the highest net benefit ( 69558.42 birr ha $^{-1}$ ) with marginal rate of return of $1475.41 \%$ was recorded from the application of 200kg NPSB ha- ${ }^{-1}$ with EH1493 variety. Therefore, application of $200 \mathrm{~kg}$ NPSB $\mathrm{ha}^{-1}$ with EH1493 variety is recommended to be used by farmers around Walmera district.
\end{abstract}

Keywords: Food barley, NPSB fertilizers, proximate analysis, grain quality content

DOI: $10.7176 / \mathrm{FSQM} / 104-01$

Publication date: January $31^{\text {st }} 2021$

\section{INTRODUCTION}

Barley (Hordeum vulgare L.) is most important cereals in the world in terms of both quantities produced and cultivated areas, annually, harvested area was about 140 million tons, obtained from 50 million hectares (FAOSTAT, 2018). In the world, it ranks the fourth most important cereal crop, after wheat, maize, and rice, belonging to family Poaceae. Ethiopia is considered as a center of diversity for barley, because of the presence of great diversity in ecology (Lakew et al., 1997). It was categorized among the top ten crop plants in the world (ICARDA, 2011). Similarly, barley production in the world was around 15.87 million tons more than previous year's projection, compared to last year production, represent an increase of 15.87 million tons or $12.33 \%$ in barley production around the globe (USDA, 2019). Its average yield globally, changed during the time starting from $1.39 \mathrm{t} \mathrm{ha}^{-1}$ in 1960 to $2.99 \mathrm{t} \mathrm{ha}^{-1}$ in 2018 (USDA, 2018). European Union, Russia, Canada, USA and Argentina are the top five barley producers globally; European Union produces the greatest quantities of barley with an estimated production of 20.5 million tons followed by Russian federations with a production of about 8 million tons, whereas Canada, USA and Argentina barley production was estimated 7.3, 3.1 and 2.8 million tons, respectively (USDA, 2017).

In Ethiopia barley is one of the most important widely used staple food cereal crop next to tef, maize, wheat, and sorghum (CSA, 2017). Barley cultivation is reported to have started 5000 years ago in Ethiopia (Jamal et al., 2016) and was probably first cultivated by Agew people in about 3,000 B.C. (Zemede, 1996). In highlands areas of Ethiopia, like Bale, Wello, North Shewa and some parts of Arsi areas have bimodal pattern of rainfall allowing barley production twice a year in summer and winter season (Alemayehu, 2011).

In Ethiopia, barley has an immense cultural and nutritional position, it can be used as food, fodder, and beverages in 20 different ways (Shewayrga and Sopade, 2011; Abraha et al., 2013). Barley in Ethiopia is mainly used for making bread, porridge, soup, and roasted grain and for preparing alcoholic and non-alcoholic drinks. Furthermore, its straw conserves as animal feed, especially during the dry season, thatching roofs, and bedding (Bekele et al., 2005). However the barley may be considered relatively underutilized with regard to its potential use as an ingredient in processed human foods (Malkki, 2004). Whole barley grain flour consisted of about 65$68 \%$ starch, $10-17 \%$ protein, 4-9\% B-glucan, 2-3\% free lipids and 1.5-2.5\% minerals (Izydorczyk et al., 2000). B-glucans the main fiber constituents in barley had been shown to lower plasma cholesterol, reduce glycemic index 
and reduce the risk of colon cancer (Brennan \& Cleary, 2005).

The low yield of food barley is primarily related to the depletion of soil fertility due to continuous nutrient uptake of crops, low fertilizer use especially $\mathrm{N}$ and $\mathrm{P}$ due to continuous cropping and insufficient organic matter application, soil $\mathrm{pH}$, poor agronomic practices and deficiency of nutrients, and low levels of fertilizer application (Agegnehu et al., 2011), and several biotic factors have contributed to this low productivity, such as use of low yielding cultivars, the limited availability of the very few improved cultivars released, weeds, insects and diseases (Woldeyesus et al., 2002). The environmental factors, such as rainfall, temperature, soil conditions, blended NPSB fertilisation and genetic factors, can contribute to variations in the chemical composition and physical characteristics of cereal grains (Rodehutscord et al ., 2016).

In addition, for the last three decades, Ethiopian agriculture depended solely on imported fertilizer products namely urea and di-ammonium phosphate (DAP) which are source of $\mathrm{N}$ and $\mathrm{P}$ although most Ethiopian soils lack other macro- and micro-nutrients (EthioSIS, 2014). According to Assefa et al., (2017) soils in the highlands of Ethiopia usually have low levels of essential plant nutrients, especially low availability of nitrogen; it is the main causes to variations in the nutritional value of cereal grains that result from biotic and abiotic factors. Evaluation of these food barley varieties across different levels of blended NPSB fertilizer helps to determine appropriate breeding objectives for improving the nutritional value of grain cereals (Rodehutscord et al., 2016).

In study area, fertilizer use trend has been focused mainly on the use and application of nitrogen and phosphorous fertilizers in the form of Di-ammonium phosphate (DAP) (18-46-0) and Urea (46-0-0) or blanket recommendation for the major food barley crop. Continuous application of nitrogen $(\mathrm{N})$ and phosphorus $(\mathrm{P})$ fertilizers without due consideration of other nutrients led to the depletion of other important nutrient elements such as potassium $(\mathrm{K})$, magnesium $(\mathrm{Mg})$, calcium $(\mathrm{Ca})$, sulfur $(\mathrm{S})$ and micronutrients in soils which were made variations cereal grain nutritional value (Abiye et al., 2004). An imbalanced fertilizer use results in low fertilizer use efficiency leading to variations in the chemical composition, physical characteristics of cereal grains, less economic returns and a greater threat to the environment and grain used in human and livestock feeding (Abiye $e t$ al., 2004).

Moreover, recently acquired soil inventory data revealed that the deficiencies of most of nutrients such as, nitrogen $(86 \%)$, phosphorus $(99 \%)$, sulfur $(92 \%)$, born $(65 \%)$ and zinc $(53 \%)$ are widespread in Ethiopian soils and similarly in study area (Ethio-SIS, 2016). Recently Ministry of Agriculture (MoA) has introduced a new brand of NPSB fertilizer having proportion of $18.9 \% \mathrm{~N}, 37.7 \% \mathrm{P}_{2} \mathrm{O}_{5}, 6.95 \% \mathrm{~S}$ and $0.1 \% \mathrm{~B}$ as main source of phosphorous, substituting DAP for adoption by farmers which is useful in improving the efficiency of fertilizer recovery there by resulting in higher crop yield and balanced barley quality to overcome the problem (MoANR, 2013). So balanced fertilization is the key to sustainable food barley grain quality enhancement and maintenance of soil health which has both economic and environmental consideration (Abiye et al., 2004). However, information on the application of blended fertilizer rate (NPSB), across their chemical composition of grain flour of recently released food barley varieties, were not determined for the study area.

Food barley varieties also released in Holeta agriculture research center, so to determine which variety; EH1493, HB1966, or HB1307 was higher responsive to NPSB blended fertilizer rates in respective to their grain qualities in the study area.

\section{MATERIALS AND METHODS}

The experiment was conducted on Holeta Agricultural Research Center (HARC) main station in 2019/2020 cropping season in West Shewa walmera district in the central highlands of Ethiopia. The rainfall is bimodal with long-term, average annual rainfall $1044 \mathrm{~mm}$. The main rainy season is from June to September and accounts for $70 \%$ of the annual rainfall and the remains from January to May and average minimum and maximum temperature 7.7 and $22.9^{\circ} \mathrm{C}$, respectively and mean relative humidity of $62 \%$ (HARC, 2019). 


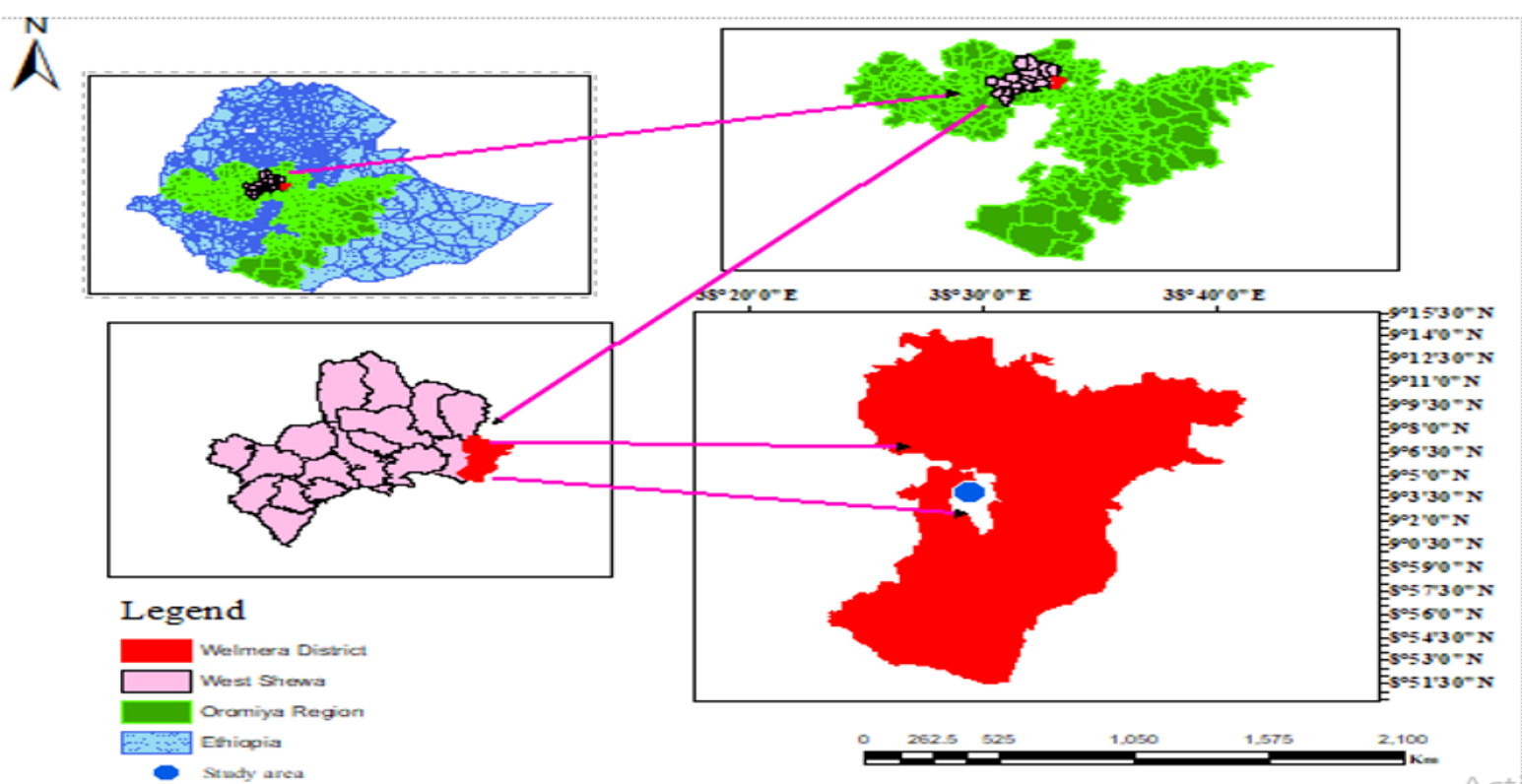

Figure 1. Map of the Study Area

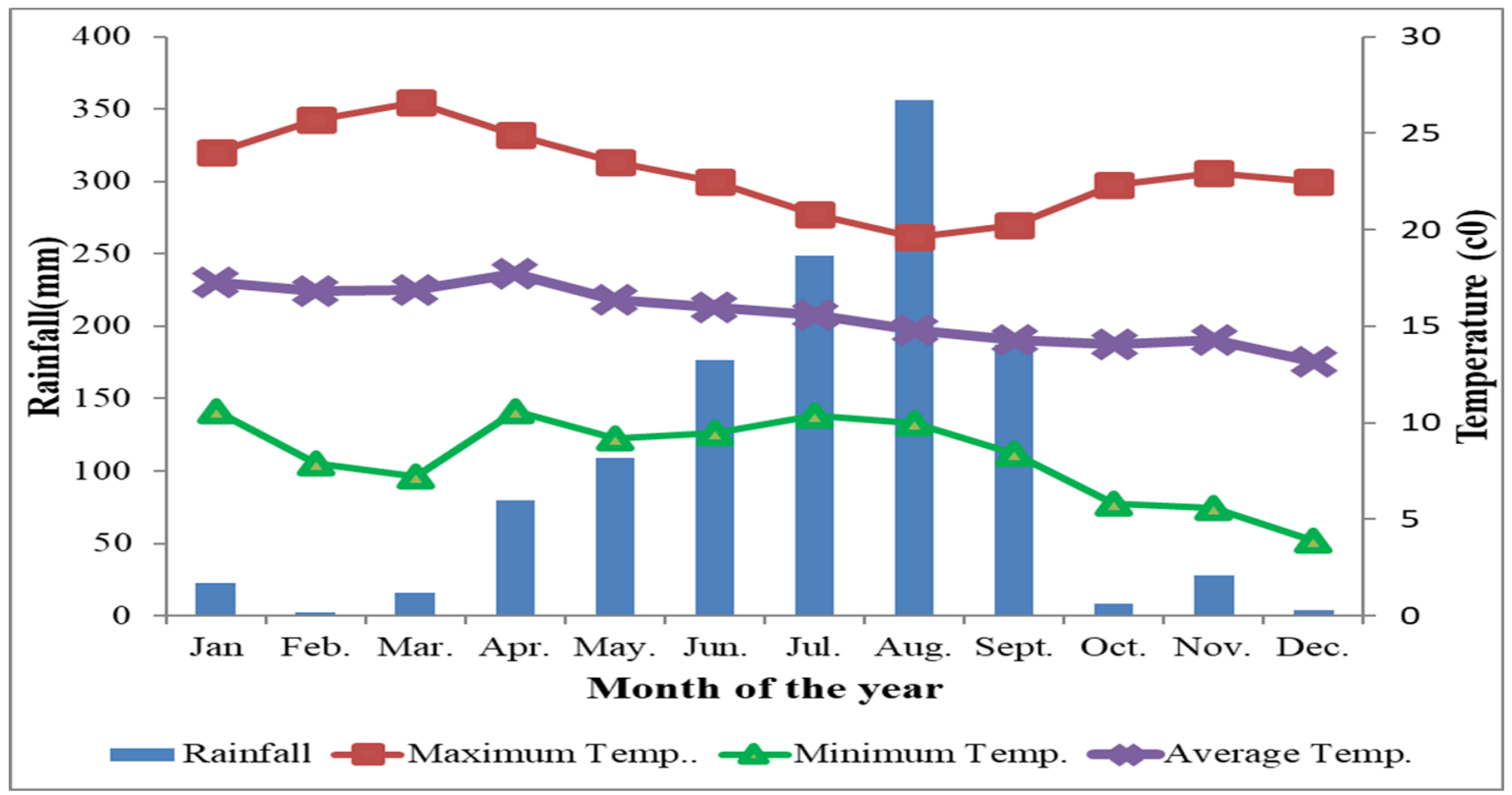

Figure 2. Mean Monthly Meteorological Data of the Study Area

The major soil type of the trial site is Nitisols (FAO, 1984; Zewdie, 2013). Ttreatments were consists of five levels of NPSB blended fertilizer $\left(0,100,150,200\right.$ and $\left.250 \mathrm{~kg} \mathrm{NPSB} \mathrm{ha}^{-1}\right)$ and one recommended NP $(60 \mathrm{~kg} \mathrm{~N} \mathrm{ha}$ ${ }^{1}$ and $69 \mathrm{~kg} \mathrm{P}_{2} \mathrm{O}_{5} \mathrm{ha}^{-1}$ ) and three varieties of food barley HB1966, EH1493, and HB-1307 (standard check). The experiment was laid out in Randomized Complete Block Design (RCBD) with factorial arrangement with three replications. The plot size was $3 \mathrm{~m}$ by $2 \mathrm{~m}\left(6 \mathrm{~m}^{2}\right)$ and the spacing between plots and blocks were 0.5 and $1 \mathrm{~m}$, respectively. The recommended Phosphorous and Nitrogen fertilizer $\left(69 \mathrm{~kg} \mathrm{P}_{2} \mathrm{O}_{5} \& 60 \mathrm{~kg} \mathrm{~N} \mathrm{ha}^{-1}\right)$ and recommended NP were applied with full dose of basal application based on treatments. The full dose of NPSB were applied at planting time close to the seed drilling line, while to avoid $\mathrm{N}$ losses by leaching, $\mathrm{N}$ fertilizer in the form of urea was applied in split application, half at planting time and the remaining half $\mathrm{N}$ fertilizer was top dressed at 35 days after planting and second weeding in the form of urea. All other recommended agronomic practices for the test crops were done as per the local research recommendations.

\section{Statistical Analysis}

The collected data were subjected to Analysis of Variance (ANOVA) using SAS version 9.3 statistical software programs. Comparisons among treatment means with significant difference for measured and scored characters were made using Duncan's Multiple Range Test (DMRT) at 5\% level of significance (SAS Institute, 2014). 


\section{RESULT AND DISCUSSION}

\subsection{Grain quality parameters of food barley}

\subsubsection{Thousand Kernel Weight}

Analysis of variance showed that thousand kernel weight $(\mathrm{TKW})$ was significantly $(\mathrm{P} \leq 0.01)$ affected by main effect of NPSB rate, however not influenced by the tested varieties and their interaction effect (Table 1). In this study thousand kernels weight obtained from the $200 \mathrm{~kg} \mathrm{ha}^{-1}$ and $250 \mathrm{~kg} \mathrm{NPSB} \mathrm{ha}^{-1}$ was significantly higher than unfertilized, which might be due to the improvement of seed quality and size as a result of balanced nutrients application. The highest mean thousand kernels weight $(48.61 \mathrm{~g})$ was obtained from the $200 \mathrm{~kg} \mathrm{NPSB}^{-1}$ and the lowest $(42.61 \mathrm{~g})$ and $(43.85 \mathrm{~g})$ was obtained from the control treatment and $100 \mathrm{~kg} \mathrm{NPSB} \mathrm{ha}^{-1}$ respectively. The more grain weight for blended fertilizer might be attributed to positive interaction of nutrients in the blended fertilizers. The results are consistent with the results of Asghari et al., (2006) who reported that the increase in fertilization rate increased thousand kernel weights. Similarly Rashid, (2010) reported that 1000 kernels weight of barley also significantly increased with all levels of fertilizers compared to control.

Even it is not significantly different among varieties, variety EH1493 gave the highest thousand kernel weight (45.79 g), while, HB1966 and HB-1307 variety recorded the less value (44.88 g) and (43.39 g) of thousand kernels weight respectively. This is may be due to the genetic variation of EH1493 variety with internal physiological factors which may led to an increased in photosynthesis process and accumulations of carbohydrate in kernel to produce heavy kernels, and consequently increased kernels weight per spike. Reports have shown variation of thousand kernels weight as a function of barley genotype (Alam et al., 2007).

Table 1. Effect of blended NPSB fertilizer rates and varieties on thousand kernels weight of food barley

\begin{tabular}{lc}
\hline & Thousand kernels weight $(\mathrm{g})$ \\
\hline 0 & $42.61^{\mathrm{c}}$ \\
100 & $43.85^{\mathrm{c}}$ \\
150 & $44.63^{\mathrm{cd}}$ \\
200 & $48.61^{\mathrm{a}}$ \\
250 & $45.3^{\mathrm{b}}$ \\
Rec. NP & $44.14^{\mathrm{cd}}$ \\
Mean & 44.69 \\
\hline LCR $(0.05)$ & 2.15 \\
\hline Varieties & \\
EH1493 & 45.79 \\
HB1966 & 44.88 \\
HB-1307 & 43.39 \\
Mean & 44.69 \\
\hline LCR $(0.05)$ & 1.52 \\
CV $(\%)$ & 5.02 \\
\hline Means followed by the same letters in the column are not significantly different at $(P<0.05)$
\end{tabular}

Means followed by the same letters in the column are not significantly different at $(P<0.05)$

\subsubsection{Moisture Contents}

Analysis of variance showed that the mean moisture content of food barley was significantly $(\mathrm{p} \leq 0.05)$ affected by the main factor varieties, while the main factor NPSB fertilizer and the interaction of the main factors did not significantly influenced grain moisture content (Table 2). The maximum average moisture content $(11.78 \%)$ was recorded from EH1493 variety which was at par with HB-1307, while the minimum average moisture content $(10.97 \%)$ was obtained from HB1966 variety. The moisture content of varieties varied between $10.00-11.9 \%$ (Biadge et al., 2017). The difference in moisture content among varieties was due to genetic variation. Moisture levels need to be low enough to inactivate the enzymes involved in seed germination as well as to prevent heat damage and the growth of disease microorganisms. Barley varieties have varied in moisture content, typically their endosperm have a much greater variation in water content capacity, which finally can affect baking performance. Their variation in water retention capacity is due to their variation with different polysaccharide and chemical composition, and levels of soluble fiber, mainly Beta-glucans (Holtekjolen, 2008).

\subsubsection{Hectoliter Weight}

Hectoliter weight is related to the flour volume obtained from a specific weight of grain. These parameters have different responses across test sites and genetic differences among varieties (Girma et al., 2012). The analysis of variance indicated that hectoliter weight $\left(\mathrm{kg} \mathrm{hl}^{-1}\right)$ was significantly $(\mathrm{p}<0.001)$ influenced by main effects of variety. However, the main effects of blended NPSB fertilizers and interactions of the two factors did not significantly influence the hectoliter weight (Table 2).

The highest hectoliter weight $\left(66.26 \mathrm{~kg} \mathrm{hl}^{-1}\right)$ was recorded from EH1493 variety, while the lowest hectoliter weight $\left(61.66 \mathrm{~kg} \mathrm{hl}^{-1}\right)$ was obtained from HB-1307 which was statistically at par with HB1966 variety (Table 2). The result of this study was in line with Rick et al., (2014) who reported that the acceptable hectoliter weights for 
barley were in the range $66.1-72.8 \mathrm{~kg} \mathrm{hl}^{-1}$. The study results showed that an acceptable hectoliter weight in EH1493 variety, but hectoliter weight of the HB1966 and HB-1307 varieties were under acceptable ranges. Including genetic differences among varieties, biotic and abiotic factors influence the plant during the period of grain fill, when stress is most likely to reduce hectoliter weight (Fox et al., 2003).

\subsubsection{Grain Size}

The analysis of variance showed that mean grain size of food barley highly significant $(p<0.001)$ varied among varieties, while the main factor NPSB fertilizer rate and the interaction of the main factors did not significantly affect grain size (Table 2). Analysis of variance showed that grain size was significantly $(\mathrm{p}<0.001)$ affected by varieties (Table 2). According to the European Brewery Convention (EBC) industry standards, large grain are based on the total percentage of grain $>2.5 \mathrm{~mm}$ (Kefale et al., 2016). High grain plumpness and uniformity are desirable quality characteristics since potential food extract is directly associated with barley grain size. The grain size percentage should be $>90 \%$ for 2-rowed barley and $>80 \%$ for 6-rowed barley (Anonymous, 2012). Accordingly, variety HB1966 mean seed sizes fulfill the standard requirements, for 6-rowed barley varieties according to EBC standard, except EH1493 and HB-1307. The maximum average grain size percentage (80.46\%) was recorded from HB1966 variety which was statistically at par with variety HB-1307; however, the minimum mean grain size (61.29\%) was obtained from EH1493 variety (Table 2). Fox et al., (2003) also mentioned that the genetic and environmental factors contribute in improving grain size, and varieties with high grain size implies in uniformity in grain size.

Table 2. Effect of blended NPSB fertilizer rates and varieties on Moisture content, Hectoliter weight, Grain size and Germination energy of food barley.

\begin{tabular}{|c|c|c|c|c|c|}
\hline Treatments & $\begin{array}{l}\text { Moisture } \\
\text { content } \\
(\%)\end{array}$ & $\begin{array}{l}\text { Hectoliter } \\
\text { Weight } \\
\left(\mathrm{kg} \mathrm{hl}^{-1}\right)\end{array}$ & $\begin{array}{l}\text { Grain } \\
\text { Size }(\%)\end{array}$ & $\begin{array}{l}\text { Germination } \\
(\%)\end{array}$ & energy \\
\hline \multicolumn{6}{|l|}{ NPSB $\left(\mathrm{kg} \mathrm{ha}^{-1}\right)$} \\
\hline 0 & 11.4 & 63.43 & 71.32 & 96.8 & \\
\hline 100 & 11.61 & 64.08 & 71.61 & 96.8 & \\
\hline 150 & 11.00 & 63.35 & 74.67 & 97.1 & \\
\hline 200 & 11.78 & 64.0 & 75.04 & 97.0 & \\
\hline 250 & 11.41 & 62.41 & 75.82 & 98.0 & \\
\hline Rec.NP & 10.91 & 63.18 & 72.47 & 96.6 & \\
\hline Mean & 11.35 & 63.41 & 73.48 & 97.05 & \\
\hline $\operatorname{LCR}(0.05)$ & $\mathrm{NS}$ & NS & $\mathrm{NS}$ & NS & \\
\hline \multicolumn{6}{|l|}{ Varieties } \\
\hline EH1493 & $11.78^{\mathrm{a}}$ & $66.26^{\mathrm{a}}$ & $61.29^{\mathrm{b}}$ & 96.7 & \\
\hline HB1966 & $10.97^{\mathrm{b}}$ & $62.31^{\mathrm{b}}$ & $80.46^{\mathrm{a}}$ & 97.3 & \\
\hline HB-1307 & $11.29^{\mathrm{ab}}$ & $61.66^{\mathrm{b}}$ & $78.74^{\mathrm{a}}$ & 97.1 & \\
\hline Mean & 11.35 & 63.41 & 73.49 & 97.03 & \\
\hline $\operatorname{LCR}(0.05)$ & 0.78 & 1.13 & 4.68 & NS & \\
\hline $\mathrm{CV}(\%)$ & 7.24 & 2.64 & 9.4 & 1.36 & \\
\hline
\end{tabular}

Means with the same letter in columns are not significantly different at 5\% of Significance level

\subsubsection{Germination Energy}

The analysis of variance for germination energy did not significantly affected $(\mathrm{P}<0.05)$ by varieties, blended NPSB fertilizer rates and their interaction (Table 2). All the varieties were successful for germination test. All varieties had above 96.7 germination energy. Similarly the germination energy did not showed significant differences among blended NPSB fertilizer rates but the germination energy varied between 96.6 - 98\%. This implies germination energy is not affected by external nutrient input, rather affected by the stored food, and the suitability of the environment for germination.

\subsubsection{Grain Protein Content}

Analysis of variances indicated that the grain protein content of food barley was significantly affected by NPSB blended fertilizer rate $(\mathrm{P}<0.001)$ and varieties $(\mathrm{P}<0.05)$. However, the interaction effect of the two factors was not significant on grain protein content (Table 3). The maximum grain protein contents of food barley $(10.31 \%)$ was recorded on $200 \mathrm{~kg}$ NPSB ha ${ }^{-1}$ fertilizer rates, while the minimum protein content $(8.37 \%)$ was obtained on the control treatment. The grain protein contents obtained with application of $200 \mathrm{~kg} \mathrm{NPSB} \mathrm{ha}^{-1}$ exceeded by about $23.17 \%$ from that of the nil or unfertilized plot with NPSB. The increase in grain protein with increasing blended fertilizer rates might be due to greater synthesis and accumulation of storage proteins. The increments of protein content in the above treatments might be due to increments of nitrogen, phosphorous and sulfur levels in the treatments. Plants absorb inorganic sulfate into two sulfur-containing amino acids, cysteine and methionine and sulfur and nitrogen had synergetic effects, when sulfur rates increase, also increase nitrogen use efficiency, which 
affects protein content of grain. The result is in line with the findings of Pomeranz and Shands, (1974) who reported the total barley grain protein composition varies from $8 \%$ to $13 \%$, with various barley grain tissues enriched with specific protein types at different levels. Similarly, Khan et al., (2003) who applied 0, 20, 40, 60, 80 and $100 \mathrm{~kg} \mathrm{~S}$ $\mathrm{ha}^{-1}$ to wheat reported that the protein content increased as the sulfur dose increased.

The highest grain protein content $(9.83 \%)$ was recorded for EH1493 variety, whereas the lowest $(9.21 \%)$ was obtained on variety HB-1307 which was at par with variety HB1966 (Table 3). The variation in grain protein content of the varieties may be attributed to their variation in nutrient uptake and translocation capacities to the sink. Moreover, the variation in protein content could be due to the genetic variation of food barley varieties. The concentrations of crude protein in barley were in general agreement with the values (7.50-10.12\%) (Jood and Kalra, 2001). Such a difference could be ascribed to the specificity of variety and environmental conditions (Oscarsson et al., 1996). Other studies have also found that protein content of barley is highly dependent on the cultivar (Qi et al., 2006) and differs with growth conditions, particularly with the rate and timing of Nitrogen and Sulfur fertilizer application (Arendt and Zannini, 2013).

\subsubsection{Grain Fat Content}

Crude fat of cereal crop was the ether extract measure of degree of fat in food products. Analysis of variance showed that the crude fat content was significantly $(\mathrm{p}<0.01)$ affected by main effects of varieties and blended NPSB fertilizer rates, however their interaction was non-significant (Table 3). The highest (2.30\%) mean value crude fat recorded from EH1493 variety which was at par with variety HB1966, while the lowest $(2.01 \%)$ mean fat value obtained from HB-1307 variety (Table 3). This variability in crude fat content could be due to inherent genetic variation among varieties. Similarly, the maximum $(2.51 \%)$ mean value crude fat content was obtained from $200 \mathrm{~kg}$ NPSB blended fertilizer rates which was at par with $100 \mathrm{~kg}$ NPSB and recommended NP rate $(60 \mathrm{~N} /$ $\left.69 \mathrm{P}_{2} \mathrm{O}_{5}\right)$, while the lowest $(1.38 \%$ ) crude fat content was recorded from control or unfertilized NPSB rate. Crude fat content of food barley grain flour showed acceptable levels that were in the range of $2.01-2.30 \%$, having an average of $2.16 \%$. Rodehutscord et al., (2016) reported that fat content of barley ranged from $1.9-4.1 \%$, and presented positive correlation with protein content. This result also in line with Faraj et al., (2004) who reported that crude fat content of food barley was ranged between 2.13 to $2.4 \%$. Similarly, the values were similar with the research findings of Baik et al., (2008) the lipid content in barley was varied from $2-2.5 \%$.

Table 3. Effect of blended NPSB fertilizer rates and varieties on grain protein content, fat content, ash content and carbohydrate content of food barley

\begin{tabular}{|c|c|c|c|c|}
\hline Treatments & $\begin{array}{l}\text { Grain protein content } \\
(\%)\end{array}$ & $\begin{array}{l}\text { Grain fat content } \\
(\%)\end{array}$ & $\begin{array}{l}\text { Grain ash content } \\
(\%)\end{array}$ & $\begin{array}{l}\text { Carbohydrate } \\
\text { content }(\%)\end{array}$ \\
\hline \multicolumn{5}{|l|}{$\begin{array}{l}\text { NPSB(kg } \\
\left.\mathrm{ha}^{-1}\right)\end{array}$} \\
\hline 0 & $8.37^{c}$ & $1.38^{\mathrm{d}}$ & $1.33^{\mathrm{c}}$ & $69.47^{\mathrm{d}}$ \\
\hline 100 & $9.3^{\mathrm{b}}$ & $2.34^{\mathrm{ab}}$ & $2.04^{\mathrm{b}}$ & $73.91^{\mathrm{c}}$ \\
\hline 150 & $9.67^{b}$ & $2.11^{\mathrm{c}}$ & $2.42^{\mathrm{a}}$ & $77.53^{b}$ \\
\hline 200 & $10.31^{\mathrm{a}}$ & $2.51^{\mathrm{a}}$ & $2.64^{\mathrm{a}}$ & $80.37^{\mathrm{a}}$ \\
\hline 250 & $9.48^{\mathrm{b}}$ & $2.24^{\mathrm{bc}}$ & $2.59^{\mathrm{a}}$ & $82.88^{\mathrm{a}}$ \\
\hline Rec.NP & $9.49^{\mathrm{b}}$ & $2.44^{\mathrm{a}}$ & $2.54^{\mathrm{a}}$ & $76.93^{b}$ \\
\hline Mean & 9.43 & 2.17 & 2.26 & 75.68 \\
\hline $\operatorname{LCR}(0.05)$ & 0.53 & 0.20 & 0.34 & 2.55 \\
\hline \multicolumn{5}{|l|}{ Varieties } \\
\hline EH1493 & $9.83^{a}$ & $2.30^{\mathrm{a}}$ & $2.43^{\mathrm{a}}$ & $77.23^{\mathrm{a}}$ \\
\hline HB1966 & $9.26^{b}$ & $2.2^{\mathrm{a}}$ & $2.33^{\mathrm{a}}$ & $75.82^{\mathrm{a}}$ \\
\hline HB-1307 & $9.21^{\mathrm{b}}$ & $2.01^{\mathrm{b}}$ & $2.01^{\mathrm{b}}$ & $73.99^{b}$ \\
\hline Mean & 9.43 & 2.17 & 2.26 & 75.68 \\
\hline $\operatorname{LCR}(0.05)$ & 0.37 & 0.14 & 0.24 & 1.81 \\
\hline CV $(\%)$ & 5.93 & 9.89 & 15.83 & 3.52 \\
\hline
\end{tabular}

Means with the same letter in columns are not significantly different at $5 \%$ of Significance level.

\subsubsection{Grain Ash Content}

Ash represents the concentration of mineral contents in a food product. Ash contents in barley grain indicate that major mineral in barley flour like phosphorous, potassium, iron and zinc (Bhatty and Christison, 2002). Analysis of variance showed that grain flour ash content was significantly different $(p<0.05)$ among varieties and main effects of blended NPSB fertilizer rates $(\mathrm{P}<0.001)$, however the interaction of the two factors were nonsignificantly different (Table 3 ). The analysis of variance showed that grain flour ash percentage was lies between $1.33 \%$ to $2.64 \%$ as a result of NPSB fertilizer treatment (Table 3). The maximum $(2.43 \%)$ mean value grain flour ash recorded form EH1493 variety which was at parity with variety HB1966 (2.33\%), while the minimum mean $(2.01 \%)$ obtained from HB-1307 variety (Table 3$)$. Whereas the highest (2.64\%) mean value grain flour ash content was obtained from $200 \mathrm{~kg}$ NPSB blended fertilizer rates, which was statistically at par with $150 \mathrm{~kg}$ 
NPSB, 250kg NPSB and the recommended NP fertilizer. While the lowest (1.33\%) grain flour ash content was recorded from control or unfertilized NPSB rate. According to Mara and Ilze, (2006) report higher crude ash content was recorded for six- row and covered barley than two- row barley genotypes. In this study also there were significant differences between barley varieties in crude ash content (Table 3). This finding was also in line with Das et al., (2015) who reported that mineral (ash) content for whole barley grains ranged from $1.22-2.9 \%$. The differences in ash content may be due to the differences in soil characteristics, climate conditions, and genetic variations. Ash content is an indication of mineral content of a food. This therefore suggests that food barley flour ash contents in acceptable range of the previous results, and could be important sources of minerals.

\subsubsection{Grain Carbohydrate Content}

Analysis of variance showed that the carbohydrate content was significantly $(p<0.01)$ affected by main effects of varieties and blended NPSB fertilizer rates, however their interaction was non-significant (Table 3). The maximum $(82.88 \%)$ carbohydrate content of food barley seeds was recorded at application $250 \mathrm{~kg} \mathrm{NPSB} \mathrm{ha}^{-1}$ blended fertilizer rate, while the lowest $(69.47 \%$ ) was obtained from application of control or unfertilized blended fertilizer rates (Table 3). The analyzed revealed that carbohydrate content of food barley increased by $10.7 \%$ and $7.2 \%$ with application of nil and $250 \mathrm{~kg}$ NPSB ha ${ }^{-1}$ over recommended NP fertilizer, respectively (Table 3). Carbohydrates account for about $65-75 \%$ of the mature barley grain (Stone and Morell, 2009), with similar values being reported for other major cereals. Similarly, Zhu, (2017) results showed that food barley seeds have significant amount of carbohydrates, mainly starch, in comparison with fruit seeds such as melon which contains $7.22 \%$ (Jacob, 2015), oilseeds such as mustard with 16.29 \% (Sharif et al., 2017) and legumes which in general contain 60\% carbohydrate (Maphosa and Jideani, (2017). Analysis of variance indicated that variety EH1493 gave the highest $(77.23 \%)$ carbohydrate percentage which was statistically at par with variety HB1966, while the HB-1307 variety had the lowest $(73.99 \%$ ) carbohydrate percentage (Table 3). The total mean carbohydrate value of three food barley varieties analyzed in this study was $75.68 \%$. Significant difference in carbohydrate content among food barley varieties was may be due to chemical composition of different barley varieties. According to Hung et al., (2011) reported that variation existed among food barley varieties for carbohydrate content was due to variation of amylose and amylopectin, amounts in varieties that have role of phosphorous rates responsible for amylopectin production, which is an essentially linear molecule consisting of glucose monomers that joined by $\alpha 1-4$ bonds.

\subsubsection{Grain Starch Content}

The starch content indicates total starch content of food barley. The extract yield implies the extent of enzymatic degradation and the solubility of grain components after mashing (Swanston et al., 2014). The fine starch content of food barley result showed that there was significant difference $(\mathrm{p}<0.05)$ among main effects of varieties (Table 4). However, the main effect of blended NPSB fertilizer rates, and the interactions of varieties and blended fertilizers were not significantly influenced starch content of food barley (Table 4). In this study, the variety with high total starch content was EH1493 (81.21\%) whereas variety with low total starch content was HB1307(78.44\%) which is statistically at par with HB1966 (78.75\%) extract values. This study result indicates these food barley varieties have comparable starch (78.44-81.21\%) with Ethiopian Brewers Corporation ranges (75.0$80.7 \%$ ) for the varieties (Kefale and Abushu, 2017).

\subsubsection{Grain Friability Content}

Friability refers to the softness and hardness of barley seed during milling or grain's resistance to being broken. The analysis of variance results showed that there were significantly different $(\mathrm{P}<0.05)$ among varieties for their friability content (Table 4). However, the main effects of blended NPSB fertilizer rates, and the interactions of varieties and blended fertilizers were non-significant (Table 4). The highest (68.43) mean friability content was obtained from EH1493 variety, which indicates laurelling (soften) performance, whereas the lowest (60.15) mean friability content was observed from HB1307 variety indicated that under modification can lead to poor mash conversion and high viscosity of polysaccharides such as beta-glucan (Dan,2013). The difference friability content among varieties was due to genetic variation. Endosperm modification of barley was interfering with impact factors, such as poor germination, large kernels and high protein, are expected to reduce barley friability (Endney and Mather, 2004). The present study result is also consistent with Kefale and Abushu, (2017) who reported that varieties with high friability ranged from 90.2 to $63.1 \%$, showed that high laurelling (friability) performance, except HB1307 food barley variety, two varieties were in acceptable range. However, all friability content among blended fertilizer rates was statistically non-significantly different. The maximum $(69.57 \%)$ friability content of food barley recorded from $200 \mathrm{~kg}$ NPSB ha ${ }^{-1}$ fertilizer rates, while the lowest $(60.17 \%)$ friability content was obtained from control or unfertilized plot (Table 4). The result of the present study is consistent with the reports of (Kefale and Abushu, 2017). 
Table 4. Effect of blended NPSB fertilizer rates and varieties on total starch, grain friability, and Beta-glucan content of food barley.

\begin{tabular}{cccc}
\hline Treatments & $\begin{array}{l}\text { Total starch } \\
\text { content }(\%)\end{array}$ & $\begin{array}{l}\text { Grain friability } \\
\text { content }(\%)\end{array}$ & $\begin{array}{l}\text { Beta-glucan } \\
\left(\mathrm{mg} \mathrm{L}^{-1}\right)\end{array}$ \\
\hline NPSB $\left(\mathrm{kg} \mathrm{ha}^{-1}\right)$ & & & 781.09 \\
0 & 78.45 & 60.17 & 776.55 \\
100 & 78.79 & 62.43 & 840.68 \\
150 & 79.55 & 64.07 & 876.11 \\
200 & 81.41 & 69.57 & 852.38 \\
250 & 78.74 & 65.1 & 756.94 \\
Rec.NP & 79.86 & 64.81 & 813.96 \\
Mean & 79.46 & 64.35 & NS \\
\hline LCR(0.05) & $\mathrm{NS}$ & $\mathrm{NS}$ & $843.96^{\mathrm{ba}}$ \\
\hline Varieties & & & $861.81^{\mathrm{a}}$ \\
EH1493 & $81.21^{\mathrm{a}}$ & $68.43^{\mathrm{a}}$ & $736.11^{\mathrm{b}}$ \\
HB1966 & $78.75^{\mathrm{b}}$ & $64.49^{\mathrm{ba}}$ & 813.96 \\
HB-1307 & $78.44^{\mathrm{b}}$ & $60.15^{\mathrm{b}}$ & 110.3 \\
Mean & 79.46 & 64.35 & 19.9 \\
\hline LCR $(0.05)$ & 2.17 & 5.93 & 13.6 \\
CV $(\%)$ & 4.04 & &
\end{tabular}

Means with the same letter in columns are not significantly different at $5 \%$ of Significance level.

\subsubsection{Grain Beta-Glucan Content}

The analysis of variance showed that there were significantly different $(\mathrm{P}<0.05)$ among varieties for their Betaglucan content (Table 4). However, the main effect of blended fertilizer rates and the interaction of the two main factors were non-significantly affected Beta-glucans content the tested varieties. The higher $\left(861.81 \mathrm{mg} \mathrm{L}^{-1}\right) \mathrm{Beta}^{-}$ glucan content was recorded on HB1966 variety which was statistically $(\mathrm{P}<0.05)$ at par with variety EH1493, while the lowest $\left(736.11 \mathrm{mg} \mathrm{L}^{-1}\right)$ was on HB1307 variety. According to Hietaniemi et al., (2000) the influence of genotype on $\beta$-glucan content is higher than the influence of environmental factors. The results are in line with Batty, (1999) who reported that beta-glucan's of barley in the acceptable range of $(2-10 \%)$.

\section{CONCLUSION}

Results of the study indicate that application of $200 \mathrm{~kg} \mathrm{ha}^{-1}$ blended NPSB fertilizer level, increased spike length, kernel per spike, grain yield, Hectoliter weight, and thousand kernel weights were increased with increased NPSB fertilizer level up to $200 \mathrm{~kg} \mathrm{ha}^{-1}$ but when NPSB fertilizer increased more than $200 \mathrm{~kg} \mathrm{ha}^{-1}$ this parameter decreased. Among tested food barley, EH1493 variety had higher yield and quality performance than others experimental varieties. Moreover, EH1493 variety with $200 \mathrm{~kg} \mathrm{ha}^{-1}$ NPSB fertilizer gave the maximum grain yield $\left(4.7 \mathrm{t} \mathrm{ha}^{-1}\right)$ and an average moisture content $(11.78 \%)$, Hectoliter weight $(66.26 \%)$, friability $(68.43 \%)$, and gave the maximum protein $(10.31 \%)$, fat (2.51\%), and ash (2.64\%), and net benefit of 69,558.42 (ETB) with a marginal rate of return (1475.41) in the study area.

\section{ACKNOWLEDGMENT}

The author is grateful the final support provided the Ethiopian Institute of Agricultural Research (EIAR) to undertake the experiment. Also my special gratitude goes to Holeta Agricultural Research Center (HARC) and agronomy research teams and soil fertility research colleagues at HARC for their technical and material support throughout the entire work.

\section{REFERENCES}

Abiye A. Tekalign M. D. Peden and Diedhiou M. 2004. Participatory on-farm conservation tillage trial in Ethiopian highland vertisols: Impact of potassium application on crop yield. Experi. Agri. 40(3): 369-379.

Abraha A, Uhlen A, Abay F, Sahlstrom S, Bjornstad A .2013. Genetic variation in barley enables a high-quality injera, the Ethiopian staple flat bread, the Ethiopian staple flat bread, comparable to Tef. Crop sci. 53(5): 2040-2050.

Agegnehu, Getachew, Minale Liben, Adamu Molla, Abraham Feyissa, Agdew Bekele, and Fite Getaneh. 2011. Research achievements in soil fertility management in relation to barley in Ethiopia. Barley Reser. and Develo. in Ethio. (2011): 137-152.

Alam M, Haider S. and Paul N. 2007. Yield and yield components of barley (Hordeium vulgare L.) cultivaries in relation to nitrogen fertilizers. Jour. of appl. Sci. res. 3:1022-1026.

Anonymous. 2012. Progress report of All India coordinated wheat and barley improvement project. 2011- 12. Vol. VI. Barley network. Directorate of Wheat Research, Karnal, India. 
Arendt E. Zannini E. 2013. Cereal Grains for the Food and Beverage Industries. Woodhead Publishing, Cambridge. 485.

Assefa F, Maqsood, M. Akbar, M. and Yousaf, N. 2017. Effect of urea fertilizer on growth response of food barley. Inter. of Jour. Agri. Bio. 3(1):59-66.

Bahtty RS .1999. beta glucan's and flour yield of barley, cereals chemis.76:314-315.

Baik, B. K. and Ullrich, S. E. 2008. Barley for food: Characteristics, improvement, and renewed interest. Jour. of Cer. Sci. 48 (2): 233-242.

Bekele B, Alemayehu F. and Berhane L. 2005. Food barley in Ethiopia. In: Grandson S, HG, Macpherson, (2005).Food Barley: Importance, Uses and Local Knowledge. Proceedings of the International Workshop on Food Barley Improvement. 14-17, January 2002.

Biadge Kefale, Ashagrie Zewdu and Berhane Lakew. 2017. Assessment of Malt Quality Attributes of Barley Genotypes grown in Bekoji, Holetta and Ankober, Ethiopia. Jour. of Agri. Sci. and Res. 4(6): 255-263.

Brennan CS \& Cleary LJ (2005) the potential use of cereal (1-3, 1-4)-B-D-glucans as functional food ingredients. J of Cereal Sci. 42: 1-13.

Central Statistical Agency (CSA). 2017. Agricultural Sample Survey 2016/17 (2009 E.C.). Volume 1. Report on area and Production of Major Crops (Private Peasant Holdings, Meher Season). Statistical Bulletin 584. Addis Ababa, Ethiopia.

Edney, MJ. and Mather, DE. 2004. Quantitative trait loci affecting germination traits and malt friability in a tworowed by six-rowed barley cross. Jour. of Cer. Sci. 39:283-290.

EthioSIS (Ethiopian Soil Information System) .2014. Soil Fertility and Fertilizer recommendation Atlas of Tigray Region. Ministry of Agriculture (MoA) and Agricultural Transformation Agency (ATA). ds of Ethiopia. Amer Jour. of Pl. Nutri. Ferti. Tech. 5(1): 1-15.

Ethio-SIS (Ethiopia Soil Fertility Status). 2016. Fertilizer Recommendation Atlas of the Southern Nations, Nationalities and Peoples' Regional State, Ethiopia. Pp 81.

FAO 1984. Geomorphology and soils of Ethiopia. In: Assistance to land use planning and provisional soil association map of Ethiopia. Field document AG DP/ETH/78/003. Food and Agriculture Organization of the UN, Rome

FAOSTAT. 2018. Food and Agricultural Organization of the United Nation. Crops. Internet. www.fao.org/faostat/en/\#data/QC Accessed: March 19, 2018.

Faraj, A. T vasanthan and R.Hoover. 2004. The effect of extrusion cooking on resistant starch formation in waxy and granular barley flours. Jour. foods res. inter.37:517-525.

Fox, G.P., Panozzo, J.F., Li, C.D., Lance, R.C., Inkerman, P.A. and Henry, R.J. 2003. Molecular basis of barley quality. Australian Jour of Agri. Res. 54: 1081-1101.

Hietaniemi V. Saastamoinen M. Kangas A. Rantanen O. and Kontturi M. 2000. $\beta$-glucan, thiamine and selenium contents in oats cultivated in Finland. Agri. Reser. Centre of Finland.

Holtekjolen. 2008. Variations in water absorption capacity and baking performance of barley varieties with different polysaccharide content and composition. Food Sci. and Tech. 41:2085.

Hung P. Tomoko M, Syota Y. Naofumi M. 2011. Effects of germination on nutritional composition of waxy barley and wheat. Jour. Sci. Food Agri. 92:667-672.

ICRISAT/ICARDA. 2011. Dry land cereals. A global alliance for improving food sufficiency, nutrition and economic growth for the world's most vulnerable poor. A CGIAR Research ICRISAT and ICARDA to the CGIAR Consortium Board.

Izydorczyk MS, Storsley J, Labossiere D, MacGregor A. W, Rossnagel BG (2000) Variation in total and soluble b-glucan content in hulless barley: effects of thermal, physical, and enzymic treatments. J of Agric and Food Chem 48:982-989.

Jood S. Kalra S. 2001. Chemical composition and nutritional characteristics of hull less and hulled barley cultivars grown in India. Nahrung/Food. 45(1): 35-39.

Kefale B, Zewdu A, Lakew B. 2016. Assessment of Malt Quality Attributes of Barley Genotypes grown in Bekoji, Holeta and Ankober, Ethiopia. Acad. Res. Jour. Agri. Sci. Res. 4(6): 255-263

Khan BA, Haq I, Ahmad E. 2003. Wheat response to sulfur application. Sarhad Jour. Agri. 19(2): 225-228.

Lakew, Asfaw B., Gebre, H. and Alemayehu, F. 1996. Barley production and research in Ethiopia. In Barley Research in Ethiopia.

Malkki Y (2004) Trends in dietary fibre research and development acta aliment 33: 39-62.

Maphosa, I. and Jideani, V. A. 2017. The Role of Legumes in Human Nutrition. In: M. Chavarri. Functional Food. Improve Health through Adequate Food. pp.103-109.

Oscarsson M. Anderson R. Salomonsson A. Aman P. 1996. Chemical composition of barley samples focusing on dietary fibre components. Jour. of Cereal Sci. 24(2): 161-170.

Qi J. Zhang G. Zhou M. 2006. Protein and hordein content in barley seeds as affected by nitrogen level and their relationship to beta-amylase activity. Jour. of Cereal Sci. 43(1): 102-107.

Rashid, S. Abate, G. Lemma, S. Warner, J. Kasa, L. and Minot, N. 2010. The Barley Value Chain in Ethiopia. 
International Food Policy Research Institute (IFPRI).

Rick, G. Ian, M. Nick, M. and Neroli, G. 2014. Western Australian malting barley varietal recommendations. Jour. of Food sci. 2: 11 -14.

Rodehutscord M., Rückert C., Maurer H. P., Schenkel H., Schipprack W., Knudsen K. E. B., Schollenberger M., Laux M., Eklund M., Siegert W., Mosenthin R. Variation in chemical composition and physical characteristics of cereal grains from different genotypes. Archives of Animal Nutrition. 2016. 70(2). P. 87107.

Sharif R. Paul R. Bhattacharjya D. and Ahmed K. 2017. Physicochemical characters of oilseeds from selected mustard genotypes. Jour. of the Bangladesh Agri. Uni. 15 (1): 27-40.

Shewayrga H, Sopade PA. 2011. Ethnobotany, diverse food uses, claimed health benefits and implications on conservation of barley landraces in North Eastern Ethiopia highlands. Jour. of Ethnobiol and Ethnomed. 7(19):1-15.

Stone and Morell. 2009. Chemistry and Technology (fourth ed.), Ame. Asso. of Cereal Chemi, St Paul, MN (2009), pp. 299-362.

United State Department of Agriculture (USDA). 2017. Ethiopia Grain and Feed Annual Report. Global Agricultural Information Network (grain) Report ET-1503. Foreign Agricultural Service, USDA, Washington, DC. RetrievedJuly22, 2017.

United State Department of Agriculture (USDA/FAS). 2018. United States Department of agriculture, Foreign Agricultural Systems. Market and Trade Data Online CustomQuery.https://apps.fas.usda.gov/psdonline/app/index.html\#app/Accessed March 10, 2018.

Woldeyesus S, Chilot Y. and Rezene F. 2002. On-farm fertilizer trial on food barley in Wolemera area. pp 266279, Proceedings of a client-oriented research evaluation workshop. Holetta Agricultural Research Centre, Holetta, Ethiopia.

Zemede Asfaw. 1996. Barley in Ethiopia: the link between botany and tradition. pp 182-192, in: Hailu Gebre and J.A.G. van Leur (eds.). Barley Research in Ethiopia: Past Work and Future Prospects. Proceedings of the 1st Barley Research Review Workshop, 16-19 October 1993, Addis Ababa.

Zewdie E. 2013. Properties of major agricultural soils of Ethiopia. Lambert Academic Publishing, Germany

Zhu F. 2017. Barley Starch: Composition, Structure, Properties, and Modifications. Comprehensive Reviews in Food Science and Food Safety. 16: 558-579. 